\title{
Use of Candida rugosa lipase immobilized on sepabeads for the amyl caprylate synthesis: Batch and fluidized bed reactor study
}

\author{
Svetlana Saponjić ${ }^{1} \cdot$ Zorica D. Knežević-Jugović $^{1} \square \cdot$ Dejan I. Bezbradica $^{1} \cdot$ Milena G. Zuza $^{1} \cdot$ \\ Omar Ali Saied ${ }^{1} \cdot$ Nevenka Bosković-Vragolović ${ }^{2} \cdot$ Dusan Z. Mijin $^{3}$ \\ 1 Department of Biotechnology and Biochemical Engineering, Faculty of Technology and Metallurgy, University of Belgrade, \\ Belgrade, Serbia \\ 2 Department of Chemical Engineering, Faculty of Technology and Metallurgy, University of Belgrade, Belgrade, Serbia \\ 3 Department of Organic Chemistry, Faculty of Technology and Metallurgy, University of Belgrade, Belgrade, Serbia
}

$\triangle$ Corresponding author: zknez@tmf.bg.ac.rs

Received April 26, 2010 / Accepted August 30, 2010

Published online November 15, 2010

(C) 2010 by Pontificia Universidad Católica de Valparaíso, Chile

\begin{abstract}
Lipase from Candida rugosa was covalently immobilized on Sepabeads EC-EP for application for amyl caprylate synthesis in an organic solvent system. Several solvents were tested in terms of biocatalyst stability and the best result was obtained with isooctane. The lipase-catalyzed esterification in the selected system was performed in batch and fluidized bed reactor systems. The influence of several important reaction parameters including temperature, initial water content, enzyme loading, acid/alcohol molar ratio, and time of addition of molecular sieves is carefully analyzed by means of an experimental design. Almost complete conversion (>99\%) of the substrate to ester could be performed in a batch reactor system, using lipase loading as low as $37 \mathrm{mg} \mathrm{g}^{-1}$ dry support and in a relatively short time $(24 \mathrm{hrs})$ at $37^{\circ} \mathrm{C}$, when high initial substrate molar ratio of 2.2 is used. Kinetics in a fluidized bed reactor system seems to still have a slightly better profile than in the batch system $(90.2 \%$ yields after $14 \mathrm{hrs}$ ). The fluidized bed reactor operated for up $70 \mathrm{hrs}$ almost with no loss in productivity, implying that the proposed process and the immobilized system could provide a promising approach for the amyl caprylate synthesis at the industrial scale.
\end{abstract}

Keywords: bioreactors, covalent immobilization, ester, non-aqueous system, optimization technique

\section{INTRODUCTION}

Amyl caprylate has characteristic fruity flavor with natural occurrence in strawberry, apple, cognac, melon, cider, and white wine. Likewise, its application in non-alcoholic beverages, ice creams, candy, baked goods, gelatins and puddings, chewing gums, cigarettes, and smokeless tobacco is reported (Welsh et al. 1989). Although flavor esters are currently produced by chemical synthesis, the use of lipases offers environmental advantages and a reduction in energy consumption. Besides, the same flavor and fragrance esters prepared by enzymatic synthesis may be labeled as "natural" (Gillies et al. 1987). Consequently, lipases have been extensively employed for direct esterification and transesterification reactions in both non-aqueous and solvent-free systems to produce esters of shortchain aliphatic carboxylic acids and alcohols such as isoamyl acetate, and butyl acetate (Krishna et al. 2000; Ozyilmaz and Gezer, 2010); ethyl butyrate, butyl butyrate and butyl isobutyrate (Yadav and Lathi, 2003; Santos and Castro, 2006; Pires-Cabral et al. 2007), ethyl valerate (Ozyilmaz and Gezer, 2010). However, the synthesis of esters of medium-chain fatty acids and monohydric alcohols including amyl caprylate here investigated, has received lesser attention in the literature (Vaidya et al. 2008).

For practical purposes, immobilized lipases are more interesting, enabling easy separation and the possibility of operation in a packed bed reactor (PBR) or fluidized bed reactor (FBR) even under extreme conditions of temperature and $\mathrm{pH}$, as well as in the presence of organic solvents (Sheldon, 
2007). However, a design of an efficient lipase immobilized system possessing high loading capacity and activity retention as well as improved stability for the esters synthesis in non-conventional media, still has many unresolved issues. Small changes in variables such as nature and characteristics of the immobilization support or conditions as well as coupling chemistry can have a significant impact on biocatalyst activity and selectivity (Mateo et al. 2007). The effect of immobilized system productivity in various reactors configurations is also a crucial factor in reactor engineering that has been identified (Truppo et al. 2008). Therefore, a comprehensive screen of immobilization supports and conditions, bioreactor design and operating regime is crucial to obtaining highly productive processes.

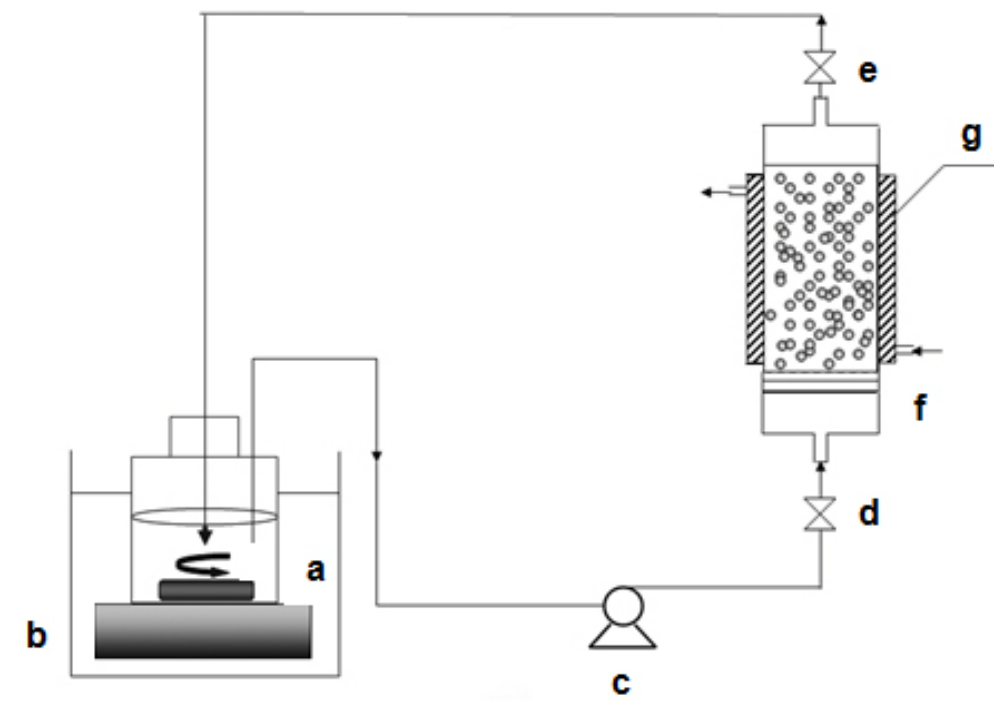

Fig. 1 Experimental setup for lipase-catalyzed esterification in FBR system. (a) Reaction mixture reservoir. (b) Reservoir temperature control. (c) Peristaltic pump. (d) Sampling valve (inlet side). (e) Sampling valve (outlet side). (f) FBR with the immobilized CRL particles. (g) Water jacket with cooling/heating water.

Among the immobilization methods, covalent attachment is the more advantageous than other methods since the rather stable systems could be obtained and diffusional restrictions to substrate or products are decreased considerably (Guisan et al. 1993; Knežević et al. 2006; Mateo et al. 2007). In this sense, supports containing epoxy groups including Sepabeads EC-EP used in this work seem to be useful to generate very intense multipoint covalent attachments with different nucleophiles placed on the enzyme molecules (amino, thiol, hydroxyl groups). Moreover, the $\mathrm{N}-\mathrm{C}$, O-C or S-C bonds formed by the epoxy groups are extremely stable, so that the immobilization protocols carefully designed to stabilize several enzymes by a multipoint covalent attachment to epoxy-activated supports appear to give impressive result concerning enzyme stabilization factor (Mateo et al. 2002). However, all these strategies have performed mainly in order to improve the enzyme stability in aqueous systems; only a few were concerned with the influence of the immobilization on the catalytic properties of the biocatalysts in non-aqueous systems (Petkar et al. 2006). For this application, the high water content in the Sepabeads as well as multi-point attachments between the matrix and enzyme could provide a stabilizing effect against the denaturing influence of the organic solvent.

The aim of this work was to improve the performance of lipase from $C$. rugosa for catalysis in a low aqueous system by immobilizing it covalently on an inexpensive and industrially applicable carrier such as Sepabeads EC-EP. The synthesis of amyl caprylate in isooctane was chosen as a model reaction in a low aqueous system. The optimization of the ester synthesis in a batch reactor system was performed by the application of the factorial design and response surface methodology. Once quasioptimum conditions for synthesis of amyl caprylate were identified, experiments were conducted in a fluidized bed reactor. The conventional FBRs are not plugging and high pressure drop problems typical of fixed bed reactors could be avoided. Thus, the bioreactor characteristic and reaction conditions were investigated to increase the reaction rate and the immobilized lipase stability. 


\section{MATERIALS AND METHODS}

\section{Chemicals}

Commercial Candida rugosa lipase (CRL; EC 3.1.1.3) was purchased from Sigma-Aldrich Chemical Co., St. Louis, MO, USA. Sepabeads EC-EP support utilized in immobilization of CRL was kindly donated by Resindion S.R.L., Mitsubishi Chem. Co., Milan, Italy. Caprylic acid and amyl alcohol were purchased from Merck, Darmstadt, Germany. A Sigma lipase substrate (St. Louis, MO, USA) was used to determine lipolytic activity in aqueous medium. Isooctane of p.a. grade purchased from Merck (Darmstadt, Germany) was dried over $3 \AA(0.3 \mathrm{~nm})$ molecular sieves for at least $24 \mathrm{hrs}$ prior to use, and as such was used for esterification activity in non-aqueous medium. All solvents used were of HPLC or analytical grade.

Table 1. Experimental setup for five-level, five-factor central composite rotatable design in terms of coded, actual values of variables and experimental data.

\begin{tabular}{|c|c|c|c|c|c|c|}
\hline $\begin{array}{l}\text { Run } \\
\text { no. }\end{array}$ & $\begin{array}{l}\text { Water } \\
\text { content }\end{array}$ & Temperature & $\begin{array}{l}\text { Enzyme } \\
\text { loadings }\end{array}$ & $\begin{array}{c}\text { Acid/alcohol } \\
\text { molar ratio }\end{array}$ & $\begin{array}{l}\text { Molecular } \\
\text { ieves }\end{array}$ & Yield \\
\hline & $X_{1} / \%$ & $X_{2} /{ }^{\circ} \mathrm{C}$ & $X_{3} / \mathrm{mg} \mathrm{g}^{-1}$ & $x_{4}$ & $X_{5} / h$ & $\mathrm{Y} / \%$ \\
\hline 1 & $1(0.7)$ & $1(55)$ & $1(49)$ & $1(2: 1)$ & $1(15)$ & 87.43 \\
\hline 2 & $1(0.7)$ & $1(55)$ & $1(49)$ & $-1(1: 1)$ & $-1(5)$ & 48.18 \\
\hline 3 & $1(0.7)$ & $1(55)$ & $-1(27)$ & $1(2: 1)$ & $-1(5)$ & 49.84 \\
\hline 4 & $1(0.7)$ & $1(55)$ & $-1(27)$ & $-1(1 ; 1)$ & $1(15)$ & 21.51 \\
\hline 5 & $1(0.7)$ & $-1(35)$ & $1(49)$ & $1(2: 1)$ & $-1(5)$ & 93.69 \\
\hline 6 & $1(0.7)$ & $-1(35)$ & $1(49)$ & $-1(1: 1)$ & $1(15)$ & 80.18 \\
\hline 7 & $1(0.7)$ & $-1(35)$ & $-1(27)$ & $1(2: 1)$ & $1(15)$ & 98.16 \\
\hline 8 & $1(0.7)$ & $-1(35)$ & $-1(27)$ & $-1(1: 1)$ & $-1(5)$ & 76.18 \\
\hline 9 & $-1(0.3)$ & $1(55)$ & $1(49)$ & $1(2: 1)$ & $-1(5)$ & 82.95 \\
\hline 10 & $-1(0.3)$ & $1(55)$ & $1(49)$ & $-1(1: 1)$ & $1(15)$ & 57.51 \\
\hline 11 & $-1(0.3)$ & $1(55)$ & $-1(27)$ & $1(2: 1)$ & $1(15)$ & 71.77 \\
\hline 12 & $-1(0.3)$ & $1(55)$ & $-1(27)$ & $-1(1: 1)$ & $-1(5)$ & 23.29 \\
\hline 13 & $-1(0.3)$ & $-1(35)$ & $1(49)$ & $1(2: 1)$ & $1(15)$ & 92.35 \\
\hline 14 & $-1(0.3)$ & $-1(35)$ & $1(49)$ & $-1(1: 1)$ & $-1(5)$ & 77.07 \\
\hline 15 & $-1(0.3)$ & $-1(35)$ & $-1(27)$ & $1(2: 1)$ & $-1(5)$ & 88.32 \\
\hline 16 & $-1(0.3)$ & $-1(35)$ & $-1(27)$ & $-1(1: 1)$ & $1(15)$ & 70.84 \\
\hline 17 & $2(0.9)$ & $0(45)$ & $0(38)$ & $0(3: 2)$ & $0(10)$ & 90.32 \\
\hline 18 & $-2(0.1)$ & $0(45)$ & $0(38)$ & $0(3: 2)$ & $0(10)$ & 78.70 \\
\hline 19 & $0(0.5)$ & $2(65)$ & $0(38)$ & $0(3: 2)$ & $0(10)$ & 36.56 \\
\hline 20 & $0(0.5)$ & $-2(25)$ & $0(38)$ & $0(3: 2)$ & $0(10)$ & 81.97 \\
\hline 21 & $0(0.5)$ & $0(45)$ & $2(60)$ & $0(3: 2)$ & $0(10)$ & 92.75 \\
\hline 22 & $0(0.5)$ & $0(45)$ & $-2(16)$ & $0(3: 2)$ & $0(10)$ & 17.30 \\
\hline 23 & $0(0.5)$ & $0(45)$ & $0(38)$ & $2(5: 2)$ & $0(10)$ & 100.00 \\
\hline 24 & $0(0.5)$ & $0(45)$ & $0(38)$ & $-2(1: 2)$ & $0(10)$ & 32.60 \\
\hline 25 & $0(0.5)$ & $0(45)$ & $0(38)$ & $0(3: 2)$ & $2(20)$ & 90.33 \\
\hline 26 & $0(0.5)$ & $0(45)$ & $0(38)$ & $0(3: 2)$ & $-2(0)$ & 76.47 \\
\hline $27^{\mathrm{a}}$ & $0(0.5)$ & $0(45)$ & $0(38)$ & $0(3: 2)$ & $0(10)$ & 73.21 \\
\hline $28^{a}$ & $0(0.5)$ & $0(45)$ & $0(38)$ & $0(3: 2)$ & $0(10)$ & 89.16 \\
\hline $29^{a}$ & $0(0.5)$ & $0(45)$ & $0(38)$ & $0(3: 2)$ & $0(10)$ & 84.51 \\
\hline $30^{\mathrm{a}}$ & $0(0.5)$ & $0(45)$ & $0(38)$ & $0(3: 2)$ & $0(10)$ & 92.65 \\
\hline $31^{a}$ & $0(0.5)$ & $0(45)$ & $0(38)$ & $0(3: 2)$ & $0(10)$ & 79.16 \\
\hline $32^{\mathrm{a}}$ & $0(0.5)$ & $0(45)$ & $0(38)$ & $0(3: 2)$ & $0(10)$ & 93.15 \\
\hline
\end{tabular}

${ }^{\text {a }}$ Central point was run in a random order. 


\section{Procedure for enzyme immobilization}

Enzyme coupling solutions containing $0.5-3.5 \mathrm{mg} \mathrm{mL}^{-1}$ of enzyme (approx. 19-135 IU) were prepared in a $1.25 \mathrm{M}$ potassium phosphate buffer at $\mathrm{pH}$ 8.0. Unmodified Sepabeads ${ }^{\circledR}$ EC-EP support $(1 \mathrm{~g}$ dry weight) was incubated with $70 \mathrm{~mL}$ of enzyme solutions in a shaking water bath (150 rpm) at $25^{\circ} \mathrm{C}$ during the $48 \mathrm{hrs}$. After incubation, the beads were collected by vacuum filtration using a glass filter (Whatman), washed with $1 \mathrm{M} \mathrm{NaCl}(3 \times 20 \mathrm{~mL})$, afterwards with potassium phosphate buffer, $\mathrm{pH} 8.0$ (3 $x 20 \mathrm{~mL}$ ) and stored in it at $4^{\circ} \mathrm{C}$ until use. The samples of the filtrate and enzyme coupling solutions before immobilization, together with the washing solutions, were taken for analysis. The amount of bound protein was determined indirectly from the difference between the amount of protein introduced into the coupling solution and the amount of protein in the filtrate and in the washing solutions. Enzyme loading $\left(P_{\mathrm{g}}, \mathrm{mg} \mathrm{g}^{-1}\right)$ and specific activity of the immobilized enzyme $\left(S A, I U \mathrm{mg}^{-1}\right)$ were determined from the following equations:

$$
P_{g}=\frac{\left[C_{0} V_{0}-\left(C_{1} V_{1}+C_{2} V_{2}\right)\right]}{w}
$$

[Equation 1]

$S A=\frac{U}{P_{g}}$

[Equation 2]

where $C_{0}$ is the protein concentration of the enzyme coupling solution ( $\left.\mathrm{mg} \mathrm{mL}^{-1}\right) ; V_{0}$ its volume $(\mathrm{mL}) ; C_{1}$ the protein concentration of the filtrate $\left(\mathrm{mg} \mathrm{mL}^{-1}\right) ; V_{1}$ the filtrate volume $(\mathrm{mL}) ; C_{2}$ the protein concentration of washing solution $\left(\mathrm{mg} \mathrm{mL}^{-1}\right)$ and $V_{2}$ its volume $(\mathrm{mL}) ; w$ the weight of support used $(\mathrm{g})$; and $U$ the hydrolytic activity of the immobilized enzyme $\left(I U \mathrm{~g}^{-1}\right)$.

\section{Catalytic properties of the immobilized CRL in an aqueous system}

The effect of $\mathrm{pH}$ on the immobilized $\mathrm{CRL}$ activity was studied by varying the $\mathrm{pH}$ of the standard test between 6.0 and 8.5 at $37^{\circ} \mathrm{C}$. The assays were allowed to take place in $0.1 \mathrm{M}$ potassium phosphate buffers. The effect of temperature on the immobilized lipase activity was determined at temperatures from 25 to $65^{\circ} \mathrm{C}$ under assay conditions. Aiming to perform thermal stability assays, the immobilized $\mathrm{CRL}$ was incubated in $25 \mathrm{mM}$ phosphate buffer, $\mathrm{pH} 7.0$ at $50^{\circ} \mathrm{C}$. At intervals, the samples were taken and the residual activity of the biocatalyst was determined according to the standard procedure. The enzyme inactivation has been modeled according to the one-stage first-order kinetics and the biocatalyst half-life has been determined, as previously described (Knežević et al. 2006).

\section{Stability of the immobilized CRL in organic solvents}

The stability of free and immobilized CRL was assessed under non-reactive conditions by incubating the biocatalysts in $5 \mathrm{~mL}$ of anhydrous solvents (methanol, 1-butanol, chloroform, benzene, $n$-pentane, $n$-hexane and isooctane) at $30^{\circ} \mathrm{C}$ for $48 \mathrm{hrs}$. After that, both free and immobilized lipase mixture was dried under vacuum to remove solvent. Initial and final enzyme activities were then measured at $37^{\circ} \mathrm{C}$ in standard conditions. Initial activities were defined as $100 \%$.

\section{Esterification reaction in a batch reactor system}

Esterification reactions in a batch reactor system took place with the immobilized CRL in isooctane in screw-capped $100 \mathrm{~mL}$ vials with a working volume of $10 \mathrm{~mL}$. Amyl alcohol and caprylic acid were added at different molar ratios followed by different amounts of water, according to the experimental design. The reaction mixture was then incubated at different temperatures on a shaker at $150 \mathrm{rpm}$ prior to the addition of the immobilized lipase. The immobilized enzyme $(0.5 \mathrm{~g})$ with varying enzyme loadings was added in the reaction mixture only after the correct temperature was attained and samples were taken for analysis after $24 \mathrm{hrs}$. Molecular sieves were added to remove water formed during the reaction at indicated time. Control experiments were also conducted without lipase under similar conditions. 

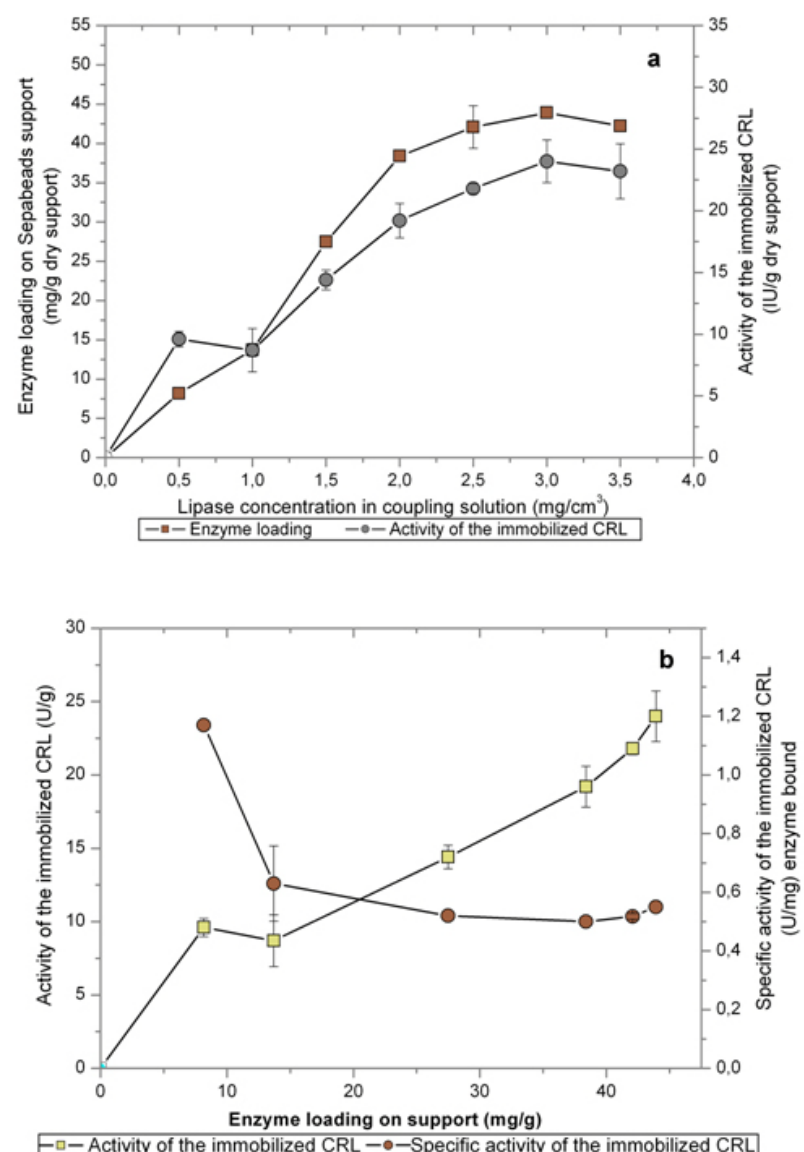

Fig. 2 Activity and the specific activity of the immobilized lipase. (a) As a function of lipase concentration in coupling solution. (b) Enzyme loading.

A five-level-five-factor central composite rotatable design (CCRD) was employed in this study, requiring 32 experiments, which consisted of 16 factorial points, 10 axial points and 6 central points. The initial water content $(0.1-0.9 \% \mathrm{w} / \mathrm{v})$, reaction temperature $\left(25-65^{\circ} \mathrm{C}\right)$, enzyme loading $\left(16-60 \mathrm{mg} \mathrm{g}^{-1}\right)$, acid/alcohol molar ratio (1:2-5:2) and time of addition of molecular sieves $(0-20 \mathrm{hrs})$ were the variables investigated. These variables were chosen based on the results obtained in a preliminary study and are the most commonly used for modeling esterification reactions (Krishna et al. 2000; Chiang et al. 2003; Knežević-Jugović et al. 2008). The ester yield in mol\% (Y\%) was taken as the response variable.

The design of experiments employed as well as the variables and their levels selected for developing the model are presented in Table 1. To avoid bias, 32 runs were performed in a totally random order. The data obtained were fitted to a second-order polynomial equation:

$$
Y=\beta_{0}+\sum_{i=1}^{5} \beta_{\mathrm{i}} X_{\mathrm{i}}+\sum_{i=1}^{5} \beta_{\mathrm{ii}} X_{\mathrm{i}}^{2}+\sum_{i=1}^{4} \sum_{j=i+1}^{5} \beta_{\mathrm{ij}} X_{\mathrm{i}} X_{\mathrm{j}}
$$

\section{[Equation 3]}

here $\beta_{0}, \beta_{\mathrm{i}}, \beta_{\mathrm{ii}}$ and $\beta_{\mathrm{ij}}$ are regression coefficients for intercept, linear, quadratic and interaction terms, respectively and $X_{i}$ and $X_{j}$ are independent variables. The coefficients of the response function and their statistical significance were evaluated by the method of least squares by using the MATLAB software. Response surfaces and contour plots were obtained using the fitted model, by keeping independent variables at a constant value while changing the other two variables. 


\section{Esterification reaction in a fluidized bed reactor (FBR)}

Flow pattern analysis. The fluid flow patterns in reactor were investigated by using tracer response analysis. The aim was to fully understand some of the operational characteristics of the FBR. Distribution of residence time in a reactor is essential tool for affirming the velocity profile of a flowing fluid. In this experiment, we have disturbed the system by introducing a step input of the tracer and then monitored how the system responded to this stimulus. Non-reactive black ink was a tracer since it did not modify the hydrodynamic conditions, and its concentration could be easily analyzed in the effluents of the reactor by spectroscopy at $400 \mathrm{~nm}$, as was described (Knežević et al. 2004). The obtained tracer concentration profiles were normalized with respect to the inlet tracer concentration and resulting normalized $c / c_{0}$ functions represent experimental $F$ curves. Experimental $E$ curves (exit age distribution functions) could be then obtained by derivation, as follows:

$$
E=\frac{d F}{d t}_{\text {[Equation 4] }}
$$

In this study a tanks-in-series model was used to characterize non-ideal flow within the reactor:

$$
\begin{aligned}
& F=1-e^{(-N \theta)}\left[1+N \theta+\frac{(N \theta)^{2}}{2 !}+\ldots+\frac{(N \theta)^{N-1}}{(N-1) !}\right] \\
& E=N^{N} \frac{\theta^{N-1}}{(N-1) !} e^{-(N \theta)} \quad \text { [Equation 6] }
\end{aligned}
$$

\section{[Equation 6]}

[Equation 5]

where $N$ is the number of stirred tanks, $\theta=t / \bar{t}$ is the dimension-less time, $\bar{t}$ is mean residence time in the whole system.

Bioreactor setup for lipase-catalyzed esterification. Fluidized bed reactor (FBR) configuration was also employed for the lipase-catalyzed esterification reaction. The reactor consisted of cylindrical glass column (10 mm, internal diameter x $136 \mathrm{~mm}$, length) and an external water jacket for temperature control. The column was packed with $1.2 \mathrm{~g}$ of immobilized enzyme $\left(3.75 \mathrm{~cm} \mathrm{~g}^{-1}\right.$, density $\left.1.13 \mathrm{~g} \mathrm{~mL}^{-1}\right)$ and the reaction mixture $(80 \mathrm{~mL})$ was fed upwards through the column using a peristaltic pump at different flow rates. Prior to entry into the column, the substrate mixture consisted of caprylic acid and amyl alcohol in stoichiometric proportion was heated to a predetermined temperature by a magnetic stirrer. The esterification was carried out by recirculation of the reaction mixture through the FBR in the semi-continuous mode of operation. The samples were taken at different time intervals and analyzed for ester content (Figure 1).

Analysis. Hydrolytic activities of free and immobilized CRL were assayed by the standard olive oil emulsion method and expressed as international units (IU), as previously described (Knežević et al. 2006). $1 \mathrm{IU}$ is defined as the amount of the enzyme required to produce $1 \mu \mathrm{mol}$ of free fatty acid per minute at $37^{\circ} \mathrm{C}$ and $\mathrm{pH}$ 7.7. Protein concentration was determined according to Bradford method using the starting enzyme preparation as a standard (Bradford, 1976). Moisture content of the immobilized CRL was determined by Karl Fischer titration method.

Esterification reactions were monitored by determination of the residual acid content by titration against standard sodium hydroxide using phenolphthalein as an indicator and methanol as a quenching agent. The molar conversion was determined from the values obtained for the blank and the test samples. Reactions were also monitored by measuring the ester concentration by gas chromatography (model: 
Varian 3400) equipped with a Carbowax 20-M column ( $3 \mathrm{~m}$ length, $3.175 \mathrm{~mm}$ internal diameter) and flame ionization detector (FID). Nitrogen was used as a carrier gas with a flow rate of $30 \mathrm{~mL} \mathrm{~min}^{-1}$. Column oven, injection part, and detector temperatures were at 100,200 , and $250^{\circ} \mathrm{C}$, respectively. The reported percentage ester yield was defined as the amount of ester produced to initial substrate in defect (mol ester/mol initial substrate in defect $x$ 100). The percentage of esterification determined by both GC analysis and titration were found to be in good agreement.

\section{RESULTS AND DISCUSSION}

\section{Lipase immobilization and characterization}

The method for lipase immobilization on Sepabeads EC-EP involves a direct enzyme binding on the polymer via epoxy groups. For high efficiency and activity recovery, the covalent attachment of enzyme to a support depends not only on the method of attachment but also on the enzyme concentration. Thus, our initial experiments were carried out to determine the effects of lipase concentration in the coupling solution in the range of $0.5-3.5 \mathrm{mg} \mathrm{mL}^{-1}$ on the enzyme loading on Sepabeads as well as activity of the immobilized enzyme. The results are shown in Figure 2.

Enzyme loading increased rapidly with increasing concentration of enzyme in the coupling solution and then reached a maximum value of $45.2 \pm 3.1 \mathrm{mg} \mathrm{g}^{-1}$, representing $18.5 \%$ of the initial enzyme amount (Figure 2a). Accordingly, the hydrolytic activity of the immobilized lipase appears to increase as more lipase was loaded onto the support, reaching a maximum value of $24 \mathrm{IU} \mathrm{g}^{-1}$ at $43.9 \pm 0.51 \mathrm{mg} \mathrm{g}^{-1}$ dry support (Figure 2b). However, it is apparent that lower specific activities were obtained at higher enzyme loadings, possibly due to mass transfer problems associated with diffusion of substrate and product into the support particles and access to the enzyme's active site. When recovered activity of the immobilized enzyme is analyzed (ratio of specific activity of the immobilized enzyme and of the free one), it seems that the highest efficiency of $98.3 \%$ was obtained at the lowest enzyme loading explored. However, the loading of $43.9 \pm 0.51 \mathrm{mg} \mathrm{g}^{-1}$ seems to be more appropriate for use, resulting also in a rather high recovered activity of $82.9 \pm 2.0 \%$ with satisfactory amount of protein bound.

Some other properties of the immobilized CRL were: $\mathrm{pH}$ optimum 7.5 ; temperature optimum $45-47^{\circ} \mathrm{C}$; biocatalyst half-life determined from thermal stability assays in an aqueous system at $50^{\circ} \mathrm{C}$ was 5.41 hrs (data not shown). The $\mathrm{pH} /$ temperature activity profile of the immobilized lipase was closely similar to that of the free enzyme although the apparent optimum temperature for oil hydrolysis was increased by $5^{\circ} \mathrm{C}$ after enzyme immobilization. The half-life time of lipase at $50^{\circ} \mathrm{C}$ in the aqueous system was increased from $1.64 \mathrm{hrs}$ to $5.41 \mathrm{hrs}$ after immobilization (data not shown). It is worth noting that similar results were reported by other authors for immobilization of various enzymes on epoxy-activated supports, describing subtle changes in the $\mathrm{pH} /$ temperature activity profile after immobilization (Kunamneni et al. 2008; Çelem and Önal, 2009). Overall, these results are similar or favorable compared with those reported in the literature for covalently immobilized CRL on different supports in terms of both recovered activity and thermal stability (Hung et al. 2003; Gomes et al. 2004; Knežević et al. 2006), but much lower than those reported for the lipase covalently immobilized on different agarose (Otero et al. 1988).

The stability study of free and immobilized $\mathrm{CRL}$ in various organic solvents at $30^{\circ} \mathrm{C}$ revealed that the immobilization method produces an appreciable stabilization of the biocatalyst in a non-aqueous system, as expected for an enzyme immobilized by the multipoint covalent attachment (Figure 3). To quantify the effect of the organic solvent on the enzyme activity, the log $P$ concept was applied. The $\log P$ is defined as the logarithm of the partition coefficient of the solvent in a standard mixture of 1 octanol and water. It appears that the immobilized lipase stability in organic solvent is correlated with the solvent hydrophobicity $(\log P)$ with the highest residual activities obtained in $n$-hexane $(\log P=3.5)$ and isooctane $(\log P=4.5)$. Strong deactivation of both lipase forms occurred in methanol $(\log P=-$ $0.76)$ and in 1 -butanol $(\log P=0.8)$. Although the stability in both chloroform $(\log P=2)$ and benzene $(\log P=2)$ is slightly higher than in $n$-pentane $(\log P=3)$, an apparent positive correlation between the stabilization factor and the solvent $\log P$ was observed (Figure 3 ). This agrees with literature data on solvent effects on enzyme activity, indicating a denaturing effect of hydrophilic solvents as a result of the dehydration of the enzyme microenvironment (Laane et al. 1987). 


\section{Amyl caprylate synthesis}

Amyl caprylate synthesis in a batch reactor system. The purpose of our research is to study the performance of the immobilized CRL for synthetic reactions in the non-aqueous system. The synthesis of amyl caprylate was chosen as the case study, for being an already known ester of current interest. RSM and 5-level-5-factor CCRD were used to optimize and understand the relationship between the important reaction parameters. RSM is an optimization technique that determines the optimum process condition by testing several variables at a time, uses special experimental designs to cut the number of required determinations. In addition, this technique allowed us to quantify the individual effect of each factor and to investigate their possible interactions.

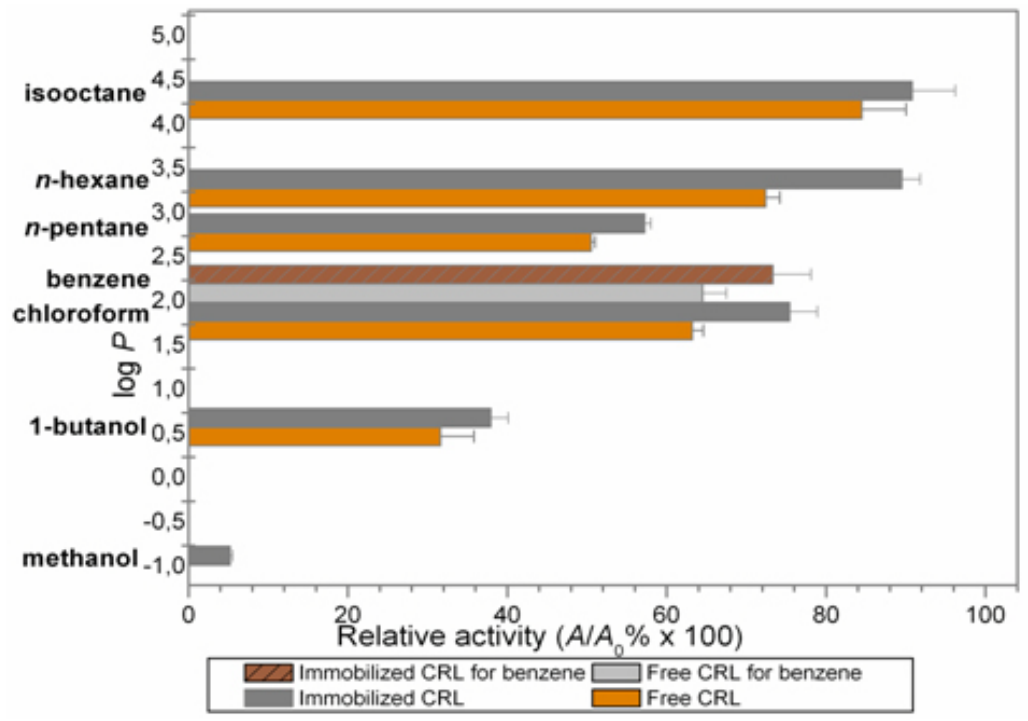

Fig. 3 Relative activity as a function of $\log P$ of various organic solvents for free and immobilized lipases.

The final response equation obtained after eliminating the insignificant terms was as follows:

$$
Y=87.00-13.60 X_{2}+1130 X_{3}+14.40 X_{4}-6.11 X_{2}^{2}-7.18 X_{3}^{2}-4.35 X_{4}^{2}+6.27 X_{2} X_{3}
$$

\section{[Equation 7]}

Both $t$-test and $p$-value statistical parameters were used to confirm the significance of the factor studied. Linear regression coefficients representing effects of substrate molar ratio, temperature, and enzyme loading were found to be significant, with applied significance level of $p<0.05$. Three quadratic terms representing the same factors were also significant. All of quadratic coefficients had negative values indicating that response is quadratic function with local maximums, enabling determination of optimum values of all significant factors. Additionally, statistical analysis led to revealing just one interaction factor, between temperature and enzyme loading was also significant. Interestingly, effect of water content on the conversion was not significant and could be neglected in the range of test. Perhaps, it is because water content in this range was sufficient to preserve the catalytic conformation of the enzyme and the immobilized CRL itself contains sufficient water to maintain its activity $\left(0.93 \%(\mathrm{w} / \mathrm{w})\right.$ stored in air at $\left.4^{\circ} \mathrm{C}\right)$. In general, it is observed that only a very small amount of water is needed to successfully use enzymes in organic solvents, however the optimal level of water should be determined for particular reaction system (Carta et al. 1991). Higher amounts of water could have only an unfavorable effect on the equilibrium conversion. Besides, the water is one of the products generated by the reaction, thus the use of molecular sieves as a strategy for the control of the water content in the system appears to be promising. The water content and time of addition of molecular sieves were constant at 0 level $(0.5 \%, 10 \mathrm{hrs})$ in the following discussion. 
The fit of the model was checked by the $R^{2}$, which was calculated to be 0.912 , indicating that $91.2 \%$ of the variability in the response could be explained by the model. The model also showed statistically insignificant lack of fit, as is evident from the lower calculated $F$ value than the theoretical $F$ value at $5 \%$ level. The plot of experimental values of ester yield (\%), versus those calculated from the above equation, indicated a good fit with a correlation coefficient, $r$ of around 0.902 (data not shown). Overall, these results revealed good correspondence between predicted and experimental values, implying that the empirical model derived from RSM can be used to adequately describe the relationship between the factors and response in the lipase-catalyzed synthesis of the amyl caprylate.

Figure 4 and Figure 5 show the response surface plot and contour plots for the predicted values for the yield of ester versus any two of the variables by fixing the remaining at its center point value. Temperature showed a positive interactive effect with the enzyme loading, indicating that higher enzyme loading could compensate for the lower reaction rates at higher temperatures (Figure 4a). The maximum yield of ester could be obtained when working at low temperatures reaching a value close to $95 \%$ at $37^{\circ} \mathrm{C}$ for the enzyme loading of around $40 \mathrm{mg} \mathrm{g}^{-1}$. The result suggests that the $\mathrm{C}$. rugosa lipase, like some other lipases such as Novozym SP 435 from C. antarctica (Yadav and Lathi, 2003) or Lipozyme IM-20 from R. miehei (Chowdary et al. 2002) was inactivated when it is subjected to a high temperature for a long period under non-aqueous conditions. Likewise, the similar behavior during the synthesis of butyl butyrate with $\mathrm{CRL}$ immobilized on styrene-divinylbenzene copolymer was observed since a decrease in yield by $39 \%$ was recorded when temperature changed from 37 to $50^{\circ} \mathrm{C}$ (Santos and Castro, 2006).

(a)
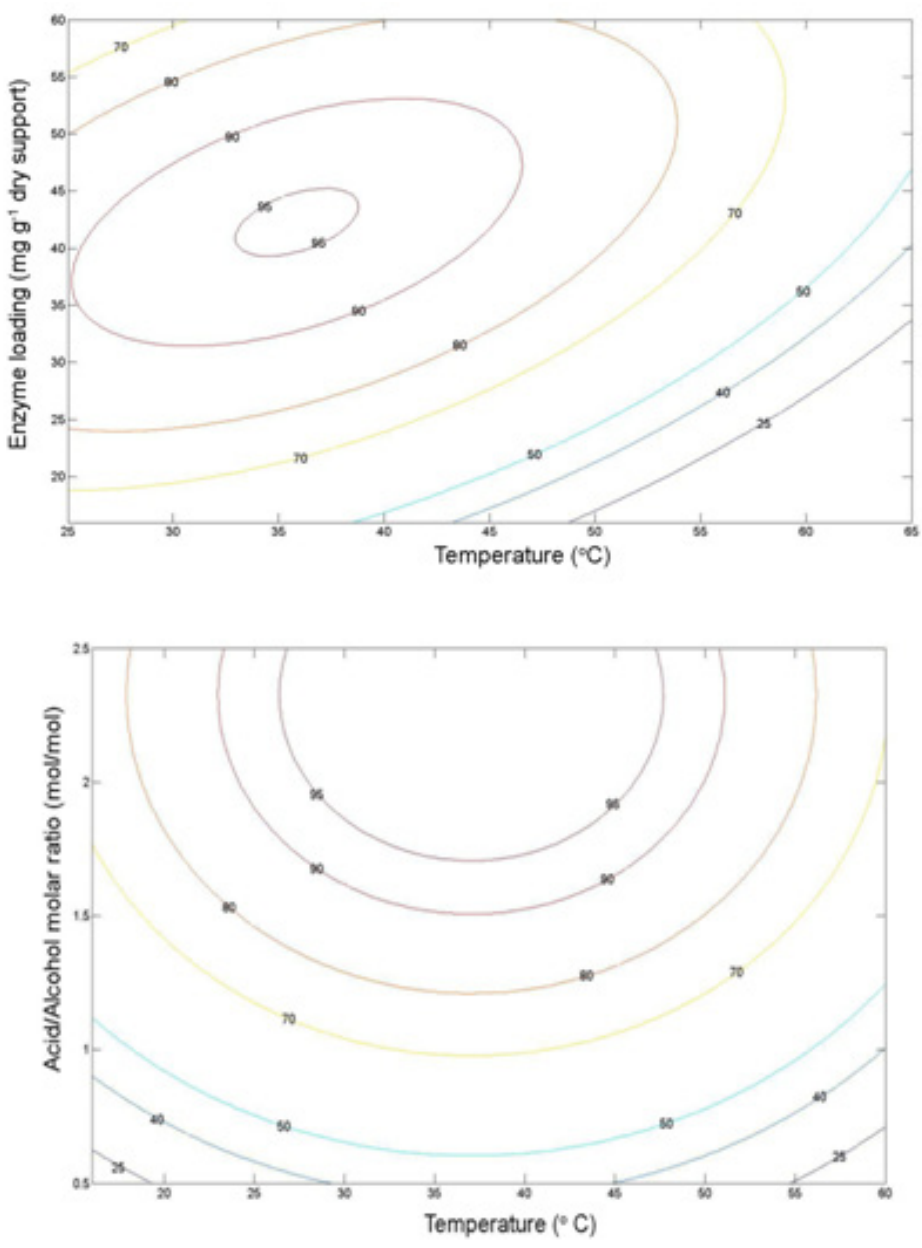

(b)

Fig. 4 Contour plots for the ester yield. (a) As a function of temperature and enzyme loading. (b) Temperature and substrate molar ratio. Other reaction parameters are constant at 0 level. 
Other important parameter affecting the economic feasibility of the process is the acid to alcohol molar ratio (Figure $4 \mathrm{~b}$ ). It seems that while temperature exerted a negative influence, acid excess had a significant positive effect on ester yield, indicating the importance of using an excess of acid compared with the stoichiometric amount for maximum conversion to the ester. Beneficial effect of excess acyl donor was also observed for the synthesis of short-chain esters using microbial lipases by several authors (Chowdary et al. 2002; Yadav and Lathi, 2003). In an excess of fatty acid, most of the enzyme is found in the acylated form, preventing it from binding the product. In addition, a higher concentration of free acid in the reaction system was beneficial to the incorporation of acid from the view of reaction equilibrium, but excessive free fatty acid could also result in substrate inhibition (Carta et al. 1991; Vaidya et al. 2008). In our experimental setup, the substrate molar ratio had positive influence on the ester yield and we found that the acid did not inactivate catalyst in concentrations up to $1.25 \mathrm{M}$.

(a)
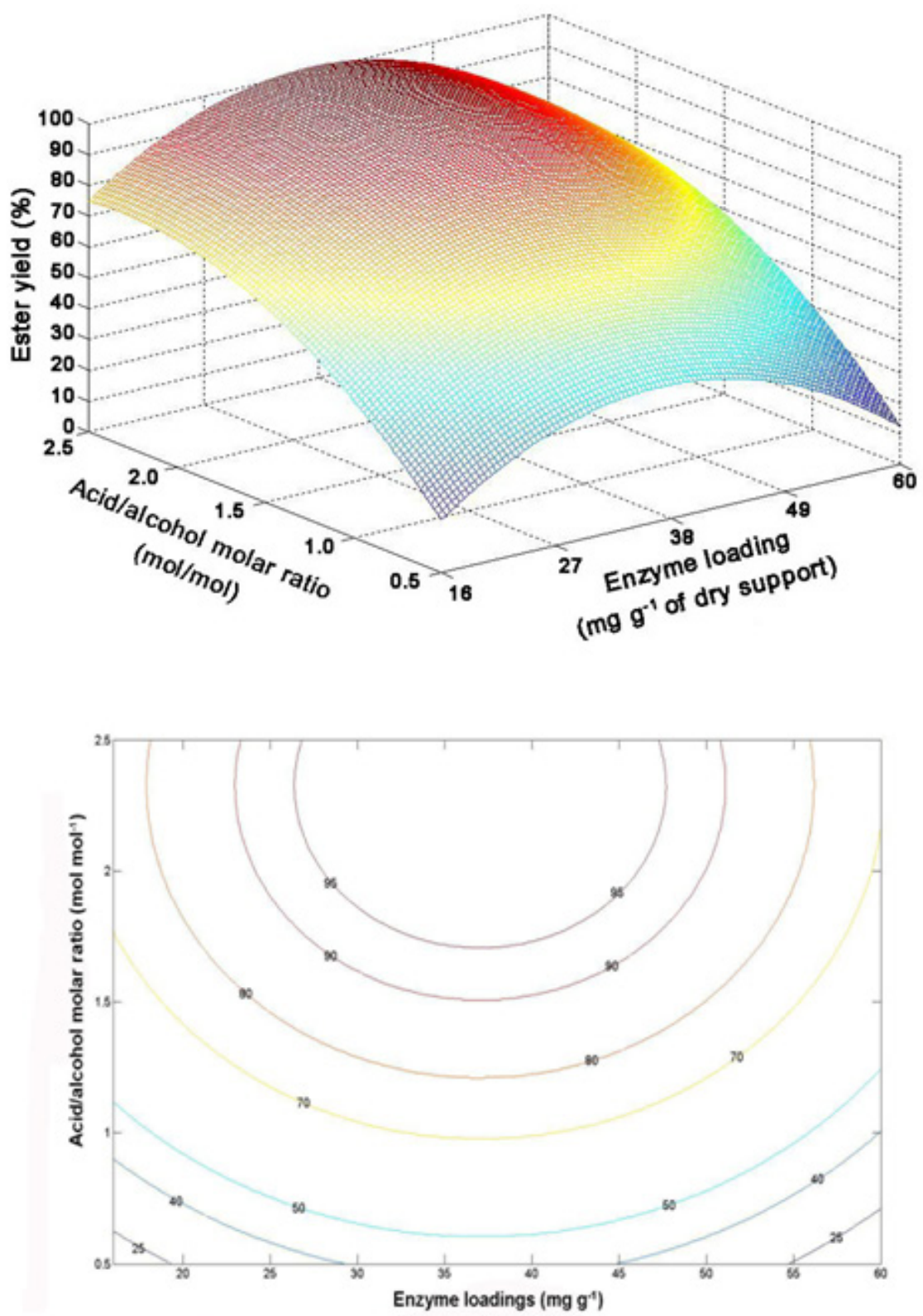

(b)

Fig. 5 Response surface and contour plots for the ester yield. (a) Response surface. (b) As a function of lipase loading and substrate molar ratio. Other reaction parameters: $24 \mathrm{hrs} ; 45^{\circ} \mathrm{C}$. 
The most interesting result of the part of study focused on the statistically analyzed influence of enzyme loading and initial substrate molar ratio in a 3-dimensional graph (Figure 5a). Figure 5b shows the contour plot for the predicted values of ester yield as a function of the enzyme loadings at different acid/alcohol molar ratios after $24 \mathrm{hrs}$ incubation at $45^{\circ} \mathrm{C}$. Ester production is represented by a convex surface described by a second order polynomial with a maximum at an enzyme loading of about $37 \mathrm{mg}$ $\mathrm{g}^{-1}$ of dry support for a molar acid/alcohol ratio equal to about 2.2. Higher enzyme loadings led to a reduced ester yield, indicating a possible mass transfer limitation. It appears that high yields are possible with a relatively small amounts of enzyme when high substrate molar ratio levels are used, which is beneficial from the economic viewpoint since the cost of enzyme is usually higher than that of substrates. In general, the lipase concentrations required to achieve higher yields of esters are often too high and reaction times relatively too long for industrial application (Welsh et al. 1990). In this study, it was shown that high conversion of around $99 \%$ could be achieved at $0.5 \mathrm{M}$ alcohol concentration (substrate in defect), using amounts of enzyme as low as $37 \mathrm{mg} \mathrm{g}^{-1}$ (E/S ratio of $\sim 4 \mathrm{~g}$ $\mathrm{mol}^{-1}$ ) and in a relatively short time $(24 \mathrm{hrs})$ at fixed acid/alcohol molar ratio of 2.2 .

\section{Amyl caprylate synthesis in a FBR system}

Flow pattern studies. Based on the promising results obtained in the batch system, we have developed a FBR system for amyl caprylate synthesis. The knowledge of flow patterns and reaction kinetics as well as process parameters optimization is essential for the proper design of an enzyme bioreactor. Flow patterns in the tubular FBR were investigated at two different flow rates: 3 and $10 \mathrm{~mL}$ $\mathrm{min}^{-1}$. Representative $F$ and $E$ curves obtained experimentally (symbols) and by the best fit of the series stirred tanks model (lines) are shown in Figure 6. Generally, good agreement of the model and experimental results was obtained (STD < 4\%) such that the reactor in the investigated range of flow

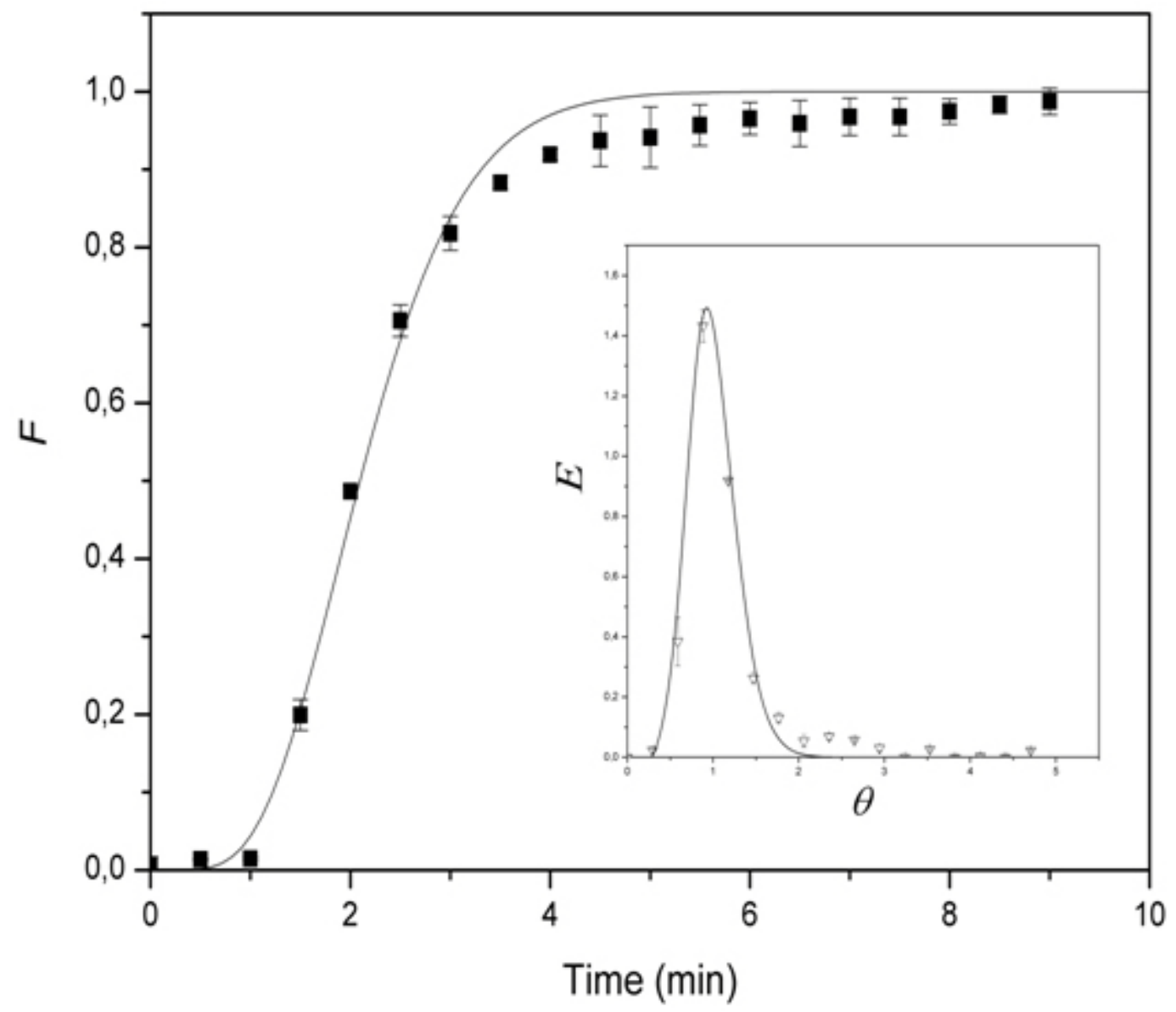

Fig. 6 Representative $\boldsymbol{F}$ and $\boldsymbol{E}$ curve in FBR. Flow rate of $10 \mathrm{~mL} \mathrm{~min}^{-1}, N=13$. Symbols represent experimental data. Lines represent predictions of the tank in series model. 
rates could be described with 5 to 13 tanks in series. Specifically, as the flow rate increased from 3 to $10 \mathrm{~mL} \mathrm{~min}{ }^{-1}$, the number of tanks in series increased from 5 to 13 , approaching ideal flow to some extent. Thus, it seems that the tubular fluidized reactor could be essentially considered as an ideal plug flow reactor with slight deviations. At flow rate of $10 \mathrm{~mL} \mathrm{~min}^{-1}$, the mean residence time of the $E$ curve was calculated to be $0,9 \mathrm{~min}, 15.1 \%$ lower than the calculated residence time based on the reactor volume and the flow rate, indicating approximately the same portion of the reactor volume $(15 \%)$ as a dead region.

Substrate flow rate effect. In a preliminary study, it was found that as was the case for a batch reactor study, operation of the $\mathrm{FBR}$ at $35^{\circ} \mathrm{C}$ is preferable to operation at higher or lower temperatures. It was also clearly shown that the major factor affecting the ester synthesis reaction was the time spent in reactor, governing the time of contact between enzyme and substrates.

With the goal of affirming relationship between the conversion and residence time a set of experiments at various flow rates of substrate mixture was carried out. Flow rate and residence time have a reciprocal relationship. The substrate mixture was fed upwardly from the bottom of the column at flow rates between 3.0 and $14.15 \mathrm{~mL} \mathrm{~min}^{-1}$, corresponding to residence times between $3.53 \mathrm{~min}$ and 0.75 min, respectively. Data characterizing the dependence of the conversion on the operation reactor time at different residence time are shown in Figure 7 for reaction at $35^{\circ} \mathrm{C}$.

From the course of the curves, it is shown that the observed reaction rate increases with residence time. Thus, it appears that the external mass transfer do not constitute a rate determining step in the ester synthesis in FBR system under the conditions tested in the study. Increased flow rate led to reduction of contact time between the enzyme surface and substrates; the reaction was incomplete and so, the ester yield was reduced. H-Kittikun et al. (2008) also found that yield of monoacylglycerols increased with decreasing in substrate flow rate for continuous glycerolysis in the packed-bed reactor system. Results of this experiment revealed a maximum conversion level of $90.2 \%$ at flow rate of 3.0 $\mathrm{mL} \mathrm{min}^{-1}$ after $14 \mathrm{hrs}$, suggesting that kinetics in FBR system seems to still have a slightly better profile than in the batch system.

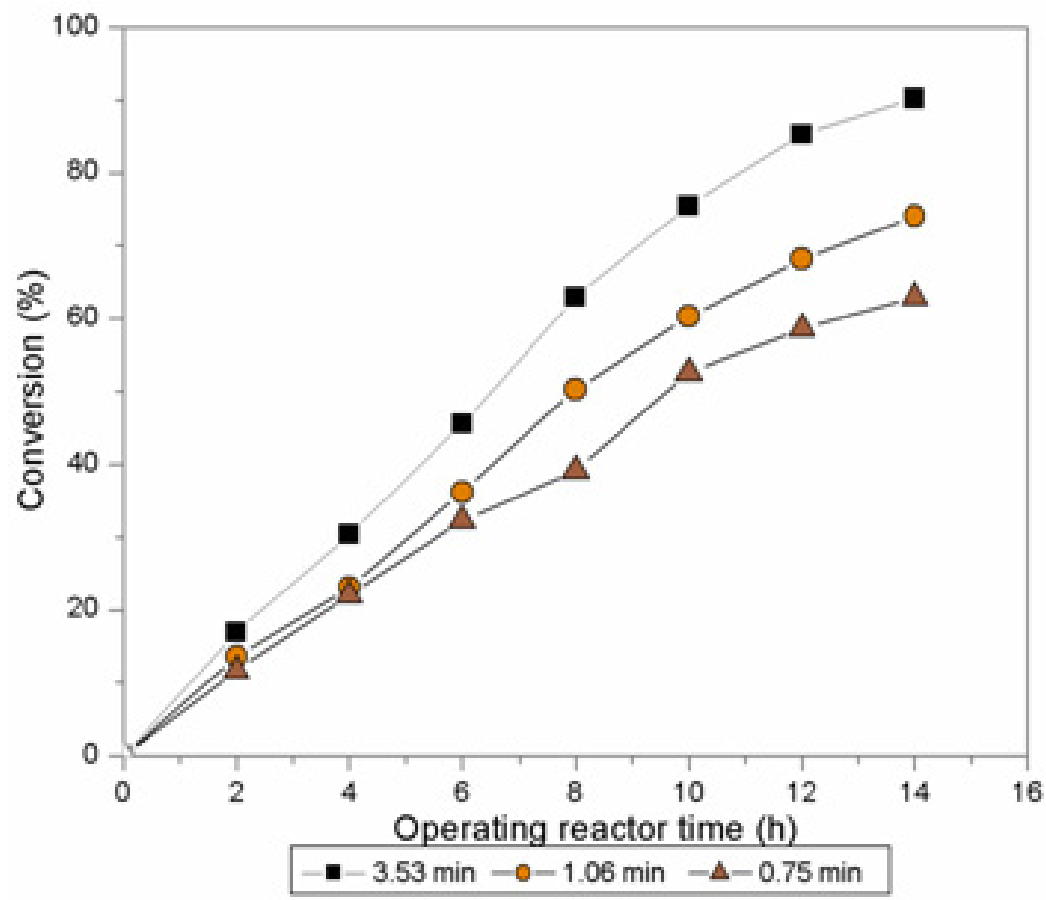

Fig. 7 Effect of residence time on production of amyl caprylate in FBR system. Reaction conditions: $35^{\circ} \mathrm{C}$; enzyme loading $37 \mathrm{mg} \mathrm{g}^{-1}$, substrate molar ratio $1: 1$. 
Long-term stability assay. The relevance of the designed FBR in ester synthesis was affirmed in relation to its behavior over long time continuous operation. It appears that mass transfer limitations were not observed at low flow rates while high flow rates in reactor could increase lipase desorption. As a result, flow rate of $3 \mathrm{~mL} \mathrm{~min}^{-1}$ and enzyme loading of $37 \mathrm{mg} \mathrm{g}^{-1}$ were chosen for the reactor stability study. The semi-continuous mode has been applied, which consisted of cycles of esterification reactions conducted for six days with a succession of $14 \mathrm{hrs}$ synthesis. Completion of each cycle was followed by enzyme removal from reactor, washing with fresh solvent and drying overnight at room temperature in a silica gel dryer. The re-use performance with successive operations up to six runs is shown in Figure 8.

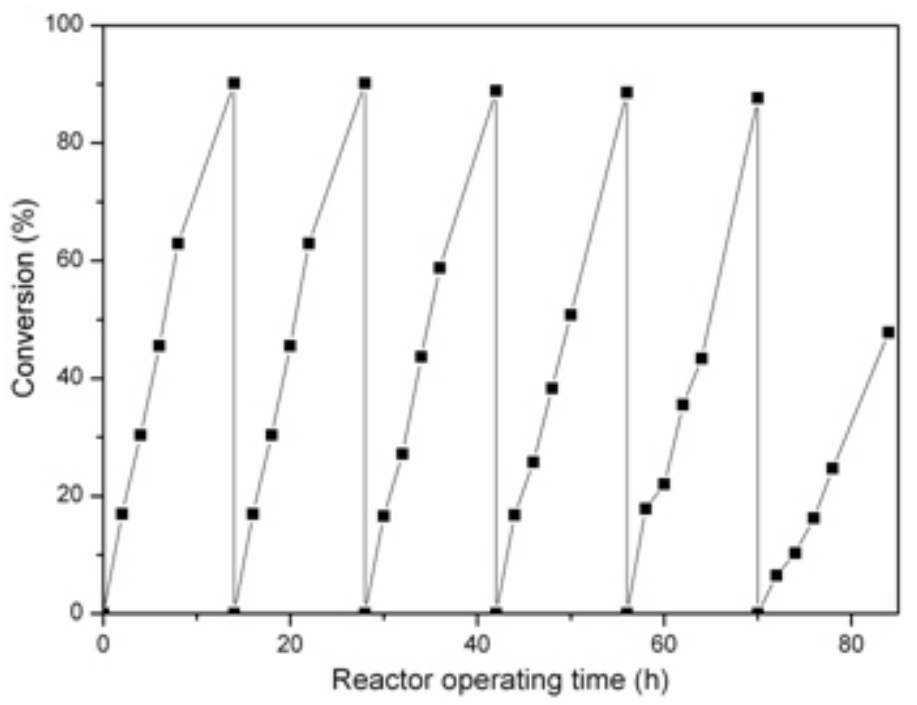

Fig. 8 Ester synthesis as a function of reactor operating time for a repetitive batch experiment in FBR system. Reaction conditions: flow rate $3 \mathrm{~mL} \mathrm{~min}^{-1}$; $35^{\circ} \mathrm{C}$; enzyme loading $37 \mathrm{mg} \mathrm{g}^{-1}$; substrate molar ratio 1:1.

The immobilized CRL remained stable over five reaction cycles with little disruption in productivity (70 hrs) where after the activity rapidly went down, showing a half-life of less than 80 hrs. Due to the recorded increase in mass after each cycle, it would seem that much of this loss of enzyme activity was due to product or substrates inhibition. It is plausible that adsorption of the polar product or substrates onto the biocatalyst surface occurred. Such hypothesis was proposed previously in the study of transesterification between triolein and ethanol in $n$-hexane, where accumulation of polar product occurred due to its low solubility in organic solvent resulting with diffusion limitations of the substrate from the organic phase to the enzyme (Marty et al. 1997). Due to the differences in the reaction systems and lack of enzyme loadings in the system/or on the support reported in the stability studies it is, however, difficult to compare these results with the literature data. Roughly, the results of operational stability of CRL immobilized on Sepabeads ${ }^{\circledR}$ EC-EP are similar to results of previous studies performed with lipases in packed bed or FBR or even higher (Marty et al. 1997; Piao et al. 2004).

This work provides preliminary results on the use of Sepabeads EC-EP as a support matrix for immobilizing CRL and on the application of the resulting derivative to amyl caprylate synthesis as a study model. The esterification reaction in non-conventional media was chosen for this assay because the ultimate aim of this study is to examine the feasibility of such reactions. The response surface methodology and a 5-level-5-factor central composite rotatable design were performed to identify the factors that influence the ester production and to verify whether any changes should be made in their settings to improve this reaction. The optimal conditions for the esterification in the batch reactor system were found to be: $37^{\circ} \mathrm{C}$, enzyme loading of $37 \mathrm{mg} \mathrm{g}^{-1}$, and acid/alcohol molar ratio 2.2 , while initial water content and time of addition of molecular sieves did not significantly influence the ester yield. The immobilized lipase appears to be suitable for further studied for ester synthesis in a fluidized bed reactor system. Flow pattern study revealed nearly plug flow in the reactor. Besides, analysis of the reaction rates at different flow rates shown that mass transfer issues in the boundary layers 
surrounding the beads are not significant. Operation of the reactor yielded relatively high conversion at short reaction time $(90.2 \%$ ester yield after $14 \mathrm{hrs})$ and the system has shown to be stable for up 70 $\mathrm{hrs}$, indicating that this type of reactor is an interesting option for use on an industrial scale for the production of amyl caprylate.

Financial support: This work was financed by the Ministry of Science and Technological Development of the Republic of Serbia (Project No. TR-20064).

\section{REFERENCES}

BRADFORD, M.M. (1976). A rapid and sensitive method for the quantification of microgram quantities of protein utilizing the principle of protein-dye binding. Analytical Biochemistry, vol. 72, no. 1-2, p. 248-254. [CrossRef]

CARTA, G.; GAINER, J.L. and BENTON, A.H. (1991). Enzymatic synthesis of esters using an immobilized lipase. Biotechnology and Bioengineering, vol. 37, no. 11, p. 1004-1009. [CrossRef]

ÇELEM, E.B. and ÖNAL, S. (2009). Immobilization of phytase on epoxy-activated Sepabead EC-EP for the hydrolysis of soymilk phytate. Journal of Molecular Catalysis B: Enzymatic, vol. 61, no. 3-4, p. 150-156. [CrossRef]

CHIANG, W.-D.; CHANG, S.-W. and SHIEH, C.-J. (2003). Studies on the optimized lipase-catalyzed biosynthesis of cis-3-hexen-1-yl acetate in $n$-hexane. Process Biochemistry, vol. 38, no. 8, p. 1193-1199. [CrossRef]

CHOWDARY, G.V.; DIVAKAR, S. and PRAPULLA, S.G. (2002). Modelling on isoamyl isovalerate synthesis from Rhizomucor miehei lipase in organic media: Optimization studies. World Journal of Microbiology and Biotechnology, vol. 18, no. 3, p. 179-185. [CrossRef]

GILLIES, B.; YAMAZAKI, H. and ARMSTRONG, D.W. (1987). Production of flavor esters by immobilized lipase. Biotechnology Letters, vol. 9, no. 10, p. 709-714. [CrossRef]

GOMES, F.M.; PEREIRA, E.B. and CASTRO, H.F. de. (2004). Immobilization of lipase on chitin and its use in nonconventional biocatalysis. Biomacromolecules, vol. 5, no. 1, p. 17-23. [CrossRef]

GUISAN, J.; FERNANDEZ-LAFUENTE, R.; RODRIGUEZ, V.; BASTIDA, A. and ALVARO, G. (1993). Enzyme stabilization by multipoint covalent attachment to activated pre-existing supports. In: VAN DER TWEEL, W.; HARDER, A. and BUITELAR, R. eds. Stability and Stabilization of Enzymes: Proceedings of an International Symposium Held in Maastricht, the Netherlands, 22-25 November 1992 (Studies in Organic Chemistry). Amsterdam, Elsevier, p. 55-62.

H-KITTIKUN, A.; KAEWTHONG, W. and CHEIRSILP, B. (2008). Continuous production of monoacylglycerols from palm olein in packed-bed reactor with immobilized lipase PS. Biochemical Engineering Journal, vol. 40, no. 1, p. 116-120. [CrossRef]

HUNG, T.-C.; GIRIDHAR, R.; CHIOU, S.-H. and WU, W.-T. (2003). Binary immobilization of Candida rugosa lipase on chitosan. Journal of Molecular Catalysis B: Enzymatic, vol. 26, no. 1-2, p. 69-78. [CrossRef]

KNEŽEVIĆ, Z.; KUKIĆ, G.; VUKOVIĆ, M.; BUGARSKI, B. and OBRADOVIĆ, B. (2004). Operating regime of a biphasic oil/aqueous hollow-fibre reactor with immobilized lipase for oil hydrolysis. Process Biochemistry, vol. 39, no. 11, p. 1377-1385. [CrossRef]

KNEŽEVIĆ, Z.; MILOSAVIĆ, N.; BEZBRADICA, D.; JAKOVLJEVIĆ, Z. and PRODANOVIĆ, R. (2006). Immobilization of lipase from Candida rugosa on Eupergit ${ }^{\circ} \mathrm{C}$ supports by covalent attachment. Biochemical Engineering Journal, vol. 30, no. 3, p. 269-278. [CrossRef]

KNEŽEVIĆ-JUGOVIĆ, Z.; BEZBRADICA, D.; JAKOVLJEVIĆ, Ž.; BRANKOVIĆ-DIMITRIJEVIĆ, S. and MIJIN, D. (2008). Lipase catalyzed synthesis of flavor esters in non-aqueous media: Optimization of the yield of pentyl 2-methylpropanoate by statistical analysis. Journal of the Serbian Chemical Society, vol. 73, no. 12, p. 11391151. [CrossRef]

KRISHNA, S.H.; MANOHAR, B.; DIVAKAR, S.; PRAPULLA, S.G. and KARANTH, N.G. (2000). Optimization of isoamyl acetate production by using immobilized lipase from Mucor miehei by response surface methodology. Enzyme and Microbial Technology, vol. 26, no. 2-4, p. 131-136. [CrossRef]

KUNAMNENI, A.; GHAZI, I.; CAMARERO, S.; BALLESTEROS, A.; PLOU, F.J. and ALCALDE, M. (2008). Decolorization of synthetic dyes by laccase immobilized on epoxy-activated carriers. Process Biochemistry, vol. 43, no. 2, p. 169-178. [CrossRef]

LAANE, C.; BOEREN, S.; VOS, K. and VEEGER, C. (1987). Rules for optimization of biocatalysis in organic solvents. Biotechnology and Bioengineering, vol. 30, no. 1, p. 81-87. [CrossRef]

MARTY, A.; DOSSAT, V. and CONDORET, J.-S. (1997). Continuous operation of lipase catalysed reactions in nonaqueous solvents: Influence of the production of hydrophilic compounds. Biotechnology and Bioengineering, vol. 56, no. 2, p. 232-237. [CrossRef] 
MATEO, C.; ABIAN, O.; FERNANDEZ-LORENTE, G.; PEDROCHE, J.; FERNANDEZ-LAFUENTE, R. and GUISAN, J.M. (2002). Epoxy Sepabeads: A novel epoxy support for stabilization of industrial enzymes via very intense multipoint covalent attachment. Biotechnology Progress, vol. 18, no. 3, p. 629-634. [CrossRef]

MATEO, C.; PALOMO, J.M.; FERNANDEZ-LORENTE, G.; GUISAN, J.M. and FERNANDEZ-LAFUENTE, R. (2007). Improvement of enzyme activity, stability and selectivity via immobilization techniques. Enzyme and Microbial Technology, vol. 40, no. 6, p. 1451-1463. [CrossRef]

OTERO, C.; BALLESTEROS, A. and GUISAN, J.M. (1988). Immobilization/stabilization of lipase from Candida rugosa. Applied Biochemistry and Biotechnology, vol. 19, no. 2, p. 163-175. [CrossRef]

OZYILMAZ, G. and GEZER, E. (2010). Production of aroma esters by immobilized Candida rugosa and porcine pancreatic lipase into calcium alginate gel. Journal of Molecular Catalysis B: Enzymatic, vol. 64, no. 3-4, p. 140-145. [CrossRef]

PETKAR, M.; LALI, A.; CAIMI, P. and DAMINATI, M. (2006). Immobilization of lipases for non-aqueous synthesis. Journal of Molecular Catalysis B: Enzymatic, vol. 39, no. 1-4, p. 83-90. [CrossRef]

PIAO, J.; KOBAYASHI, T.; ADACHI, S.; NAKANISHI, K. and MATSUNO, R. (2004). Continuous synthesis of lauroyl or oleoyl erythritol by a packed-bed reactor with an immobilized lipase. Process Biochemistry, vol. 39, no. 6, p. 681-686. [CrossRef]

PIRES-CABRAL, P.; FONSECA, M.M.R. da and FERREIRA-DIAS, S. (2007). Modelling the production of ethyl butyrate catalysed by Candida rugosa lipase immobilised in polyurethane foams. Biochemical Engineering Journal, vol. 33, no. 2, p. 148-158. [CrossRef]

SANTOS, J.C. and CASTRO, H.F. de. (2006). Optimization of lipase-catalysed synthesis of butyl butyrate using a factorial design. World Journal of Microbiology and Biotechnology, vol. 22, no. 10, p. 1007-1011. [CrossRef]

SHELDON, R.A. (2007). Enzyme immobilization: the quest for optimum performance. Advanced Synthesis \& Catalysis, vol. 349, no. 8-9, p. 1289-1307. [CrossRef]

TRUPPO, M.D.; POLLARD, D.J.; MOORE, J.C. and DEVINE, P.N. (2008). Production of (S)-y-fluoroleucine ethyl ester by enzyme mediated dynamic kinetic resolution: Comparison of batch and fed batch stirred tank processes to a packed bed column reactor. Chemical Engineering Science, vol. 63, no. 1, p. 122-130. [CrossRef]

VAIDYA, A.; GERA, G. and RAMAKRISHNA, S. (2008). Evaluation and optimization of immobilized lipase for esterification of fatty acid and monohydric alcohol. World Journal of Microbiology and Biotechnology, vol. 24, no. 12, p. 2987-2995. [CrossRef]

WELSH, F.W.; MURRAY, W.D.; WILLIAMS, R.E. and KATZ, I. (1989). Microbiological and enzymatic production of flavor and fragrance chemicals. Critical Reviews in Biotechnology, vol. 9, no. 2, p. 105-169. [CrossRef]

WELSH, F.W.; WILLIAMS, R.E. and DAWSON, K.H. (1990). Lipase mediated synthesis of low molecular weight flavor esters. Journal of Food Science, vol. 55, no. 6, p. 1679-1682. [CrossRef]

YADAV, G.D. and LATHI, P.S. (2003). Kinetics and mechanism of synthesis of butyl isobutyrate over immobilized lipase. Biochemical Engineering Journal, vol. 16, no. 3, p. 245-252. [CrossRef]

\section{How to cite this article:}

SAPONJIĆ, S.; KNEŽEVIĆ-JUGOVIĆ, Z.D.; BEZBRADICA, D.I.; ZUZA, M.G.; SAIED, O.A.; BOSKOVIĆVRAGOLOVIĆ, N. and MIJIN, D.Z. (2010). Use of Candida rugosa lipase immobilized on sepabeads for the amyl caprylate synthesis: Batch and fluidized bed reactor study. Electronic Journal of Biotechnology, vol. 13, no. 6. http://dx.doi.org/10.2225/vol13-issue6-fulltext-8 